\title{
$\therefore$ Preventive Measures Against COVID in Public Places
}

\section{IJCRR \\ Section: Healthcare \\ Sci. Journal Impact \\ Factor: 6.1 (2018) \\ ICV: 90.90 (2018) \\ (c) (i) (8) \\ Copyright@IJCRR}

\section{Amrithaa B. ${ }^{1}$, S. Leslie Rani ${ }^{2}$, Geetha R. V. ${ }^{3}$}

'Saveetha Dental College and Hospital, Saveetha Institute of Medical and Technical Sciences, Saveetha University, Chennai, India; ${ }^{2}$ Lecturer, Department of Pathology, Saveetha Dental College and Hospital, Saveetha Institute of Medical and Technical Sciences, Saveetha University, Chennai, India; ${ }^{3}$ Associate Professor, Department of Microbiology, Saveetha Dental College and Hospitals, Saveetha Institute of Medical and Technical Sciences, Saveetha University, Chennai, India.

\section{ABSTRACT}

Aim: The aim of the study is to analyze various preventive measures implemented to the public in the prevention and control of the spread of COVID-19.

Methods: A systematic search strategy was employed using keywords to search the literature in various medical databases like PubMed and Google scholar using keywords COVID-19, Prevention, Transmission, Symptoms, and Treatment. Over 80 articles were collected and reviewed thoroughly.

Discussion: Coronavirus disease 2019 (COVID-19) is an illness caused by a novel coronavirus, now called Severe Acute Respiratory Syndrome Coronavirus-2 (SARS-Cov-2). Prevention and control strategies and methods are in three levels: national level, case-related population level, and general population level. Patients with COVID-19 have symptoms of fever, dry cough, and tiredness and series symptoms are shortness of breath. Infection prevention and control measures that can reduce the risk of exposure of the COVID-19 include the use of face mask, covering coughs and sneezes with tissue paper, regular hand wash, avoiding contact with infected people, and not touching your eyes, nose, and mouth frequently. Restrict your travel to many states and stay home, except to make essential trips to the grocery store, and pharmacies. Masks are recommended as a potential tool when it comes to tackling the COVID-19 pandemic since the initial outbreak in China. Masks are also being used by blocking droplets ejected by the wearer thereby acting as source control. In the absence of a vaccine or effective antiviral drugs, hand hygiene may be a mainstay of efforts to stop the spread of severe acute respiratory syndrome coronavirus-2 (SARSCoV-2), the virus that causes COVID-19.

Conclusion: The only way to control is to prevent and control the spread, by physical distancing, facial mask, and use sanitizer. Key Words: COVID-19, Prevention, Transmission, Public places, Symptoms, Treatment

\section{INTRODUCTION}

Coronavirus disease 2019 (COVID-19) is an illness caused by a novel coronavirus, now called Severe Acute Respiratory Syndrome Coronavirus-2 (SARS -Cov-2) ${ }^{1}$. The coronavirus belongs to a large single-stranded RNA family virus that may cause various symptoms such as fever, breathing difficulty, and respiratory infection ${ }^{2}$. It is still too soon to anticipate powerless populaces, early examples have indicated a comparable pattern to Severe Acute Respiratory Syndrome (SARS) and Middle East Respiratory Syndrome (MERS) coronavirus ${ }^{3}$. Vulnerability is by all accounts related to age, natural sex, and other wellbeing conditions ${ }^{4,5}$. COVID-19 has now been proclaimed as a Public Health Emergency of International Concern by the $\mathrm{WHO}^{6,7}$.

Prevention and control strategies and methods are in three levels: national level, case-related population level, and general population $\operatorname{level}^{8}$. Several public health measures that may prevent the transmission of the COVID-19 are case isolation, identification and follow up of environment disinfection, and use of personal protective equipment ${ }^{9,10}$. A series of measures have been taken to reduce nosocomial infection, this includes knowledge and preparation for anticipation and control segregation, purification, grouped assurances at various degrees in disease territories, and insurance of affirmed cases $^{11}$. A bacterial infection caused by Mycobacterium spe-

\section{Corresponding Author:}

Dr. Leslie Rani, Lecturer, Department of Pathology, Saveetha Dental College and Hospital, Saveetha Institute of Medical and Technical Sciences, Saveetha University, Chennai, India; Phone: 9360293308; Email: leslieranis.sdc@saveetha.com

ISSN: 2231-2196 (Print)

Received: 24.08 .2020
ISSN: 0975-5241 (Online)

Revised: 20.09 .2020
Accepted: 15.10 .2020 
cies $^{12}$ shows similar symptoms of COVID-19 which has to be treated at an earlier stage.

For the general population, at this moment there is no vaccine to prevent COVID-19. The best way to prevent it is to avoid being exposed to the virus ${ }^{13}$. Infection Prevention and Control (IPC) measures that can reduce the risk of exposure of the COVID-19 includes use of face mask; covering coughs and sneezes with tissue which can be safely disposed, regular handwashing with soap or disinfection with hand sanitizer, avoiding contact with infected people and maintaining appropriate distance as much as possible and not touching the eyes, nose, and mouth with unwashed hands ${ }^{14}$. COVID-19 spreads mainly from patients to patients or person to person through respiratory droplets ${ }^{15}$. Some studies show that people who are infected will be asymptomatic, this plays a major role in spreading coronavirus ${ }^{16}$.

According to the centers for Disease Control and Prevention (CDC), individuals who fall into certain higher-risk categories are such as older adults and those who have serious chronic medical conditions (like heart disease or lung disease) should avoid large crowds and mass public gatherings ${ }^{17}$. The WHO emergency committee says that the number of cases reported among health care workers from hospitals was amplified due to overcrowding in public places and inadequate infection control measures ${ }^{18}$. There is much more to find out about functions related to 2019-nCOV and illnesses have ranged from mildly unwell human beings to several sick and dying ${ }^{19,20}$. Previous collected articles emphasized particularly on individual preventive measures against COVID. The current article emphasized public preventive measures against COVID-19 and to assess the preventive measures against COVID in public places.

\section{Prevention of COVID-19}

Wash your hands frequently with cleanser and water in any event for 20 seconds particularly after you have been in an open spot or subsequent to cleaning out your nose, hacking, or sniffling. Utilize a hand sanitizer that contains $60 \%$ liquor. Abstain from contacting your eyes, nose, and mouth with unwashed hands ${ }^{21}$. After touching the contaminated surface and placing a finger on the eye causes infections ${ }^{22}$. Avoid close contact with people who are sick, even inside your home. Maintain 6 feet between the person to person ${ }^{23}$. Do not gather in groups, social distancing is must ${ }^{24,25}$. CDC recommended the guidelines on face masks that people can wear cloth facecovering in public settings ${ }^{26}$. This is particularly supported in circumstances where social distancing is hard to maintain ${ }^{27}$. Likewise, careful covers and N-95 respirators ought to stay held for medicinal services workers ${ }^{28}$. Clean and disinfect frequently touched surfaces daily. If the surfaces are dirty, clean them and use household disinfectant ${ }^{29}$. In an event where you are in an open place and don't have your face secured, make sure to consistently cover your mouth and nose with a tissue when you cough or sneeze and use the inside of your elbow to cover the face (Figure 1). Dispose of used tissues in the $\operatorname{trash}^{30,31}$.

\section{COVID-19 PREVENTION}

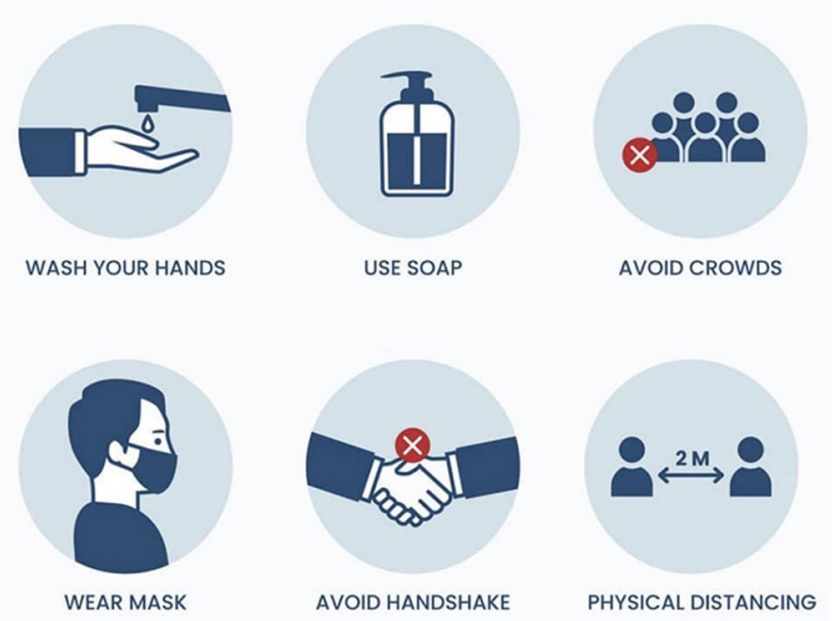

Figure 1: Figure depicts the preventive measures to be followed in order to safeguard themselves from disease-causing coronavirus.

\section{Restrict your travel}

Many states have put out the call for individuals to stay home, except to make essential trips to grocery stores, pharmacies or other outdoor activities ${ }^{32,33}$. CDC recommends that travelers avoid all non-essential travel to other states or countries ${ }^{34}$. Stay up to date with CDC's travel health notices related to this outbreak ${ }^{35,36}$. Travelling can also spread the coronavirus. Staying safe at home is better to prevent the spread of COVID-19 $9^{37,38}$.

\section{Face mask}

The science around the utilization of veils by the overall population to obstruct COVID-19 transmission is progressing rapidly ${ }^{39}$. Policymakers need critical direction on the utilization of covers by everyone as an instrument in fighting SARS-CoV-2, the respiratory infection that causes COVID-19. Veils have been prescribed as a possible instrument to handle the COVID-19 pandemic since the initial outbreak in China ${ }^{40}$. There is currently a global shortage of N95/ FFP2 respirators and surgical masks to use in hospitals ${ }^{41}$. Masks can be made of different materials and designs which influence their filtering capability ${ }^{42}$. There are thorough norms assessing veils utilized in social insurance settings however these are focused on close to Personal Protective Equipment $(\mathrm{PPE})^{43}$. Efficacy is the capacity of the veil to shield the wearer from irresistible particles ${ }^{44}$. Even substantial differences in materials and construction do not seem to 
impact the transmission of droplet-borne viruses in practice, such as a meta-analysis of N95 respirators compared to surgical masks ${ }^{45}$. Masks can also be used for source control, which refers to blocking droplets ejected by the wearer. If everyone wears masks it decreases the chance of spreading infection and being more protected ${ }^{46}$. Wearing a mask as source control is to stop the process from spreading through aerosol infection. Since big droplets dehydrate to smaller aerosol particles that can float for a longer distance in air ${ }^{47}$. A comparison of homemade and surgical masks for bacterial and viral aerosols observed that "the median fit factor of the homemade masks was protective to one-half that of the surgical masks ${ }^{48}$. Public mask-wearing is most effective in reducing the spread of the virus when compliance is high ${ }^{49}$.

\section{Hand sanitizer}

According to the Center for Disease Control (CDC) hand hygiene encompasses the cleansing of your hands by using handwashing with soap and water, antiseptic handwashes, antiseptic hand rubs such as Alcohol-Based Hand Sanitizers (ABHS), foams or gels, or surgical hand antisepsis. For many reasons, alcohol hand sanitizers as disinfectants are demanded moreover handwashing with soap and water ${ }^{50}$. Their ease of availability, no need for water or plumbing, and their proven effectiveness in reducing microbial load are the reason behind the preference ${ }^{51}$. According to the World Health Organization (WHO), an alcohol-containing preparation (liquid, gel, or foam) is designed for application to the hands to inactivate microorganisms and temporarily suppress their growth ${ }^{52}$. Viability is additionally exceptionally subject to the procedure of utilization of the liquor hand sanitizer. One must apply the item to the palm and rub the item everywhere on over the surfaces of two hands until they are dry ${ }^{53}$. Highquality hygienic hand disinfection cannot be achieved within 15 seconds, it requires 30 -second application time as ABHS has recommended. Thirty seconds is a long time to wait before proceeding with the activity. It is the same time as washing with soap and water ${ }^{54}$. The use of alcohol-based hand sanitizers has greatly increased compliance to hand hygiene in healthcare settings. They are efficient, accessible, and take relatively little time to use. Even though they have demerits like dryness of skin, they are a better antimicrobial agent than standard soap and water cleansing ${ }^{55}$. In the absence of a vaccine or effective antiviral drugs, hand hygiene may be a mainstay of efforts to stop the spread of severe acute respiratory syndrome coronavirus-2 (SARS-CoV-2), the virus that causes COVID-19. Alcohol sanitizers are used outside healthcare facilities and also in industries because they are effective at killing microorganisms better than just soap and water. There are several formulas of alcohol sanitizers that are available as gel, foam, or liquid. All healthcare workers can use alcohol sanitizers regularly and should educate the public about their benefits ${ }^{56}$. Alcohol-based hand sanitizer can kill most non-spore-forming bacteria within seconds. Al- cohol sanitizers are effective against viruses and may reduce transmission of Coronavirus ${ }^{57}$.

\section{Social distancing}

Many countries have taken unprecedented measures to prevent social contact and to slow down the spread of the virus, such as closing schools, shops, and restaurants, prohibiting public events, and stimulating or imposing working from home. These measures include "social distancing", and are especially efficient for diseases (such as COVID-19) which are transmitted by respiratory droplets and require certain proximity of people ${ }^{58}$. Social distancing measures have important effects on activity participation ${ }^{59}$. A lot of people are temporarily unemployed or work from home, and most outof-home activities are cancelled. As a result, travel demand decreases $^{60}$. COVID-19 outbreak has major implications on international travel, this viewpoint focuses on daily travel patterns ${ }^{61}$. People might avoid public transport as these can be considered a breeding ground for viruses and places where it might be difficult to avoid contact with other passengers ${ }^{62}$. As a result of social distancing, travel demand might drop due to an increased amount of working from home, e-learning, and a reduced number of public activities and events ${ }^{63}$. Since people often plan and perform out-of-home activities in order to maintain or enhance well-being, reduced activity participation as a result of social distancing can negatively affect subjective well-being ${ }^{64}$. Social distancing measures have clear direct positive effects on health, as they are implemented to avoid people getting infected by the COVID-19 virus $^{65}$. The viability and cultural effect of isolation and social separation will rely upon the validity of general wellbeing specialists, political pioneers, and establishments. It is significant that approach producers keep up the open's trust through the utilization of proof-based mediations and completely straightforward, actuality based correspondence ${ }^{66}$.

\section{nCoV Transmission}

Coronavirus is a large circle of relatives of viruses that are seen in many specific species of animals including camels, cattle, cats, and bats ${ }^{67}$. Rarely animal coronavirus can infect human beings and then unfold between people like MERS and SARS ${ }^{68,69}$. CDC considers this as a very extreme public fitness threat, primarily based on present-day information, that instant fitness change from 2019-nCov to the overall American public is taken into consideration right now ${ }^{70}$.

\section{Symptoms}

Patients with COVID-19 have the most common symptoms of fever, dry cough, and tiredness. Serious symptoms of difficulty in breathing or shortness of breath and loss of speech or movement are also recorded ${ }^{71,72}$.On average it takes 5-6 days from when somebody is contaminated with the infection for manifestations to show ${ }^{73}$. The incubation period is estimated to be between 5-14 days. 


\section{Treatment}

According to the World Health Organization, there are no specific vaccines or medicines for COVID-1974. Treatments are under investigation and will be tested through clinical trials $^{75}$. Antibiotics aren't effective against viral infections such as COVID-1976. Treatment is directed at relieving symptoms and may include pain relievers (acetaminophen) cough syrup, rest, and fluid intake ${ }^{77}$. There is no evidence that ibuprofen or Non-steroidal anti-inflammatory drugs (NSAIDS) need to be avoided ${ }^{9}$.

\section{Future scope}

To maintain healthy life and surroundings, measures such as social distancing, hand sanitizing, covering your mouth while coughing should be strictly followed and awareness should be brought to the general public regarding the consequences of improper maintaining poor health in order to safeguard themselves from future endemic diseases.

\section{CONCLUSION}

This review is necessary as of now since the prevalence of COVID-19 in public places is important. The mortality rate seems to be high in the case of COVID-19 when compared to other pandemic issues. The only way to control is to prevent and control the spread, by following the precautions. Studies exploring prevention and control measures have begun to gradually increase and these are needed to minimize the impact of the outbreak. In the future, following these precautionary measures will help not only in saving lives from present disease-causing viruses but can also help in eradicating further viruses.

\section{ACKNOWLEDGMENT}

Authors acknowledge the immense help received from the scholars whose articles are cited and included in references to this manuscript. The authors are also grateful to authors / editors / publishers of all those articles, journals, and books from which the literature for this article has been reviewed and discussed.

\section{Conflict of Interest: Nil}

Source of Funding: Nil

\section{REFERENCES}

1. SARS: How a Global Epidemic was Stopped. World Health Organization; 2006. 307 p.

2. Qiu T, Xiao H. Revealing the influence of national public health policies for the outbreak of the SARS-CoV-2 epidemic in Wuhan, China through status dynamic modeling [Internet]. Available from: http://dx.doi.org/10.1101/2020.03.10.20032995
3. Swetha S, Brundha MP. Analysis of knowledge about the hospital warning symbols among the postgraduate dental studentsA comparative study [Internet]. Vol. 10, Research Journal of Pharmacy and Technology. 2017. p. 975. Available from: http:// dx.doi.org/10.5958/0974-360x.2017.00177.9

4. Fehr AR, Channappanavar R, Perlman S. Middle East Respiratory Syndrome: Emergence of a Pathogenic Human Coronavirus [Internet]. Vol. 68, Annual Review of Medicine. 2017. p. 387-99. Available from: http://dx.doi.org/10.1146/annurevmed-051215-031152

5. Balaji S, Brundha MP, Path DNB. Awareness of About Breast Cancer among Dental Surgeons. Res J Pharm Biol Chem Sci. 2016;8(8):797.

6. 2020) (released by National Health Commission \&. National Administration of Traditional Chinese Medicine on March 3., (Released by National Health Commission \& National Administration of Traditional Chinese Medicine on March, 2020). Diagnosis and Treatment Protocol for Novel Coronavirus Pneumonia (Trial Version 7) [Internet]. Vol. 133, Chinese Medical Journal. 2020. p. 1087-95. Available from: http://dx.doi.org/10.1097/ $\mathrm{cm} 9.0000000000000819$

7. $\mathrm{Wu} \mathrm{N}$, Zhang Y, Yu Y-S. Novel coronavirus pneumonia [Internet]. Vol. 24, The Brazilian Journal of Infectious Diseases. 2020. p. 178-9. Available from: http://dx.doi.org/10.1016/j. bjid.2020.03.001

8. Wang X, Fang J, Zhu Y, Chen L, Ding F, Zhou R, et al. Clinical characteristics of non-critically ill patients with novel coronavirus infection (COVID-19) in a Fangcang Hospital [Internet]. Clinical Microbiology and Infection. 2020. Available from: http://dx.doi.org/10.1016/j.cmi.2020.03.032

9. Jodele S, Koehl JGE. Tackling COVID-19 infection through complement-targeted immunotherapy [Internet]. Available from: http://dx.doi.org/10.22541/au.158880110.01220133

10. Li J, Zhang L, Ren Z, Xing C, Qiao P, Chang B. Meteorological factors correlate with transmission of 2019-nCoV: Proof of incidence of novel coronavirus pneumonia in Hubei Province, China [Internet]. Available from: http://dx.doi. org/10.1101/2020.04.01.20050526

11. Chen P. Study on the virus transmission based on data analysis of confirmed cases of the new-type coronavirus pneumonia in China [Internet]. Available from: http://dx.doi.org/10.31219/osf. io/ek9n4

12. Brundha MP. A Comparative Study-The Role of Skin and Nerve Biopsy in Hansen's Disease. Res J Pharm Biol Chem Sci [Internet]. 2015; Available from: https:/www.researchgate.net/ profile/Brundha_Mp/publication/283561218_A_comparative study-_the_role_of_skin_and_nerve_biopsy_in_hansen's_disease/links/5892ba5d458515aeac946451/A-comparative-studythe-role-of-skin-and-nerve-biopsy-in-hansens-disease.pdf

13. Wang Y, Zhou Y, Yang Z, Xia D, Geng S. Clinical Characteristics of Patients with Severe Pneumonia Caused by the 2019 Novel Coronavirus in Wuhan, China [Internet]. Available from: http://dx.doi.org/10.1101/2020.03.02.20029306

14. Liu P, Chen W, Chen J-P. Viral Metagenomics Revealed Sendai Virus and Coronavirus Infection of Malayan Pangolins (Manis javanica) [Internet]. Vol. 11, Viruses. 2019. p. 979. Available from: http://dx.doi.org/10.3390/v11110979

15. Pan X, Chen D, Xia Y, Wu X, Li T, Ou X, et al. Asymptomatic cases in a family cluster with SARS-CoV-2 infection [Internet]. Vol. 20, The Lancet Infectious Diseases. 2020. p. 410-1. Available from: http://dx.doi.org/10.1016/s1473-3099(20)30114-6

16. Oyeniran OI, Chia T. Novel Coronavirus disease 2019 (COVID-19) outbreak in Nigeria: how effective are government interventions? [Internet]. Ethics, Medicine and Public Health. 
2020. p. 100515. Available from: http://dx.doi.org/10.1016/j. jemep.2020.100515

17. Osman N. Faculty Opinions recommendation of 2019 novel coronavirus (2019-nCoV) outbreak: A new challenge [Internet]. Faculty Opinions - Post-Publication Peer Review of the Biomedical Literature. 2020. Available from: http://dx.doi.org/10.3 410/f.737533884.793573794

18. Hohdatsu T, Okada S, Ishizuka Y, Yamada H, Koyama H. The Prevalence of Types I and II Feline Coronavirus Infections in Cats [Internet]. Vol. 54, The Journal of Veterinary Medical Science. 1992. p. 557-62. Available from: http://dx.doi. org/10.1292/jvms. 54.557

19. Cavanagh D. Coronavirus avian infectious bronchitis virus. Vet Res. 2007 Mar;38(2):281-97.

20. Hannah R, Ramani P, Brundha MP, Sherlin HJ, Ranjith G, Ramasubramanian A, et al. Liquid Paraffin as a Rehydrant for Air Dried Buccal Smear. J Adv Pharm Technol Res. 2019;12(3):1197.

21. Mizumoto K, Kagaya K, Chowell G. Early epidemiological assessment of the transmission potential and virulence of coronavirus disease 2019 (COVID-19) in Wuhan City: China, January-February, 2020 [Internet]. Available from: http://dx.doi. org/10.1101/2020.02.12.20022434

22. P Jannathulferdioz BM. Awareness of Stye. Int J Pharm Sci Rev Res,. 40(1):30-2.

23. Preethikaa S, Brundha MP. Awareness of diabetes mellitus among general population. Research Journal of Pharmacy and Technology. 2018;11(5):1825-9.

24. China NHC of TPR of, National Health Commission of the People's Republic of China. Technical guidance for laboratory testing of 2019-nCoV infection (Third Edition) [Internet]. Vol. 2, Biosafety and Health. 2020. p. 3-5. Available from: http:// dx.doi.org/10.1016/j.bsheal.2020.02.001

25. Timothy CN, Samyuktha PS, Brundha MP. Dental pulp Stem Cells in Regenerative Medicine - A Literature Review. J Adv Pharm Technol Res. 2019;12(8):4052.

26. Shenoy PB, Brundha MP. Awareness of polycystic ovarian disease among females of age group 18-30 years. J Pharm Sci [Internet]. 2016; Available from: http://search.proquest. com/openview/a8a09e7b2e9d2f967bf3fee479c7018a/1?pqorigsite $=$ gscholar \&cbl $=54977$

27. Shreya S, Brundha MP. Alteration of Haemoglobin Value in Relation to Age, Sex and Dental Diseases-A Retrospective Correlation Study. Research Journal of Pharmacy and Technology. 2017;10(5):1363-6.

28. Riou J, Althaus CL. Pattern of early human-to-human transmission of Wuhan 2019 novel coronavirus (2019-nCoV), December 2019 to January 2020. Euro Surveill [Internet]. 2020 Jan;25(4). Available from: http://dx.doi.org/10.2807/1560-7917. ES.2020.25.4.2000058

29. Hejase H. Review of "Dromedary Camels and the Transmission of Middle East Respiratory Syndrome Coronavirus (MERS-CoV)" [Internet]. 2018. Available from: http://dx.doi. org/10.14322/publons.r2297496

30. Chu DKW, Oladipo JO, Perera RA, Kuranga SA, Chan SMS, Poon LLM, et al. Middle East respiratory syndrome coronavirus (MERS-CoV) in dromedary camels in Nigeria, 2015 [Internet]. Vol. 20, Eurosurveillance. 2015. Available from: http://dx.doi. org/10.2807/1560-7917.es.2015.20.49.30086

31. Brundha MP, Haritha PS. Awareness of dengue fever among the parents of children coming to the dental outpatient department - A questionnaire study [Internet]. Vol. 3, International Journal of Clinicopathological Correlation. 2019. p. 60. Available from: http://dx.doi.org/10.4103/ijcpc.ijcpc_14_19
32. Pavli A, Tsiodras S, Maltezou HC. Middle East respiratory syndrome coronavirus (MERS-CoV): prevention in travelers. Travel Med Infect Dis. 2014 Nov;12(6 Pt A):602-8.

33. Mp B, Brundha MP, Nallaswamy D. Hide and seek in pathology- A research on game-based histopathology learning [Internet]. Vol. 10, International Journal of Research in Pharmaceutical Sciences. 2019. p. 1410-4. Available from: http://dx.doi. org/10.26452/ijrps.v10i2.606

34. Brundha MP, Visha MG. A review on ankylosing spondylitis [Internet]. Vol. 3, International Journal of Clinicopathological Correlation. 2019. p. 44. Available from: http://dx.doi.org/10.4103/ ijcpc.ijcpc_12_19

35. Zaki AM, van Boheemen S, Bestebroer TM, Osterhaus ADME, Fouchier RAM. Isolation of a novel coronavirus from a man with pneumonia in Saudi Arabia. N Engl J Med. 2012 Nov 8;367(19):1814-20.

36. van Boheemen S, de Graaf M, Lauber C, Bestebroer TM, Stalin Raj V, Zaki AM, et al. Genomic Characterization of a Newly Discovered Coronavirus Associated with Acute Respiratory Distress Syndrome in Humans [Internet]. Vol. 3, mBio. 2012. Available from: http://dx.doi.org/10.1128/mbio.00473-12

37. Al-Tawfiq JA, Memish ZA. Lack of seasonal variation of Middle East Respiratory Syndrome Coronavirus (MERS-CoV) [Internet]. Vol. 27, Travel Medicine and Infectious Disease. 2019. p. 125-6. Available from: http://dx.doi.org/10.1016/j. tmaid.2018.09.002

38. Kalaiselvi R, Brundha MP. Prevalence of hysterectomy in South Indian population [Internet]. Vol. 9, Research Journal of Pharmacy and Technology. 2016. p. 1941. Available from: http:// dx.doi.org/10.5958/0974-360x.2016.00398.x

39. Howard J, Huang A, Li Z, Tufekci Z, Zdimal V, van der Westhuizen H-M, et al. Face Masks Against COVID-19: An Evidence Review. MEDICINE \& PHARMACOLOGY. 2020.

40. Wang $\mathrm{Q}, \mathrm{Yu} \mathrm{C}$. The role of masks and respirator protection against SARS-CoV-2 [Internet]. Vol. 41, Infection Control \& Hospital Epidemiology. 2020. p. 746-7. Available from: http:// dx.doi.org/10.1017/ice.2020.83

41. Feng S, Shen C, Xia N, Song W, Fan M, Cowling BJ. Rational use of face masks in the COVID-19 pandemic [Internet]. Vol. 8, The Lancet Respiratory Medicine. 2020. p. 434-6. Available from: http://dx.doi.org/10.1016/s2213-2600(20)30134-x

42. N95 Respirators Provide No Better H1N1 Protection Than Surgical Masks [Internet]. Vol. 39, Biomedical Safety \& Standards. 2009. p. 169-70. Available from: http://dx.doi.org/10.1097/01. bmsas.0000365213.66883.ad

43. Ravichandran H, Brundha MP. Awareness about personal protective equipments in hospital workers (sweepers and cleaners). International Journal of Pharmaceutical Sciences Review and Research. 2016;40(1):28-9.

44. Dato VM, Hostler D, Hahn ME. Simple Respiratory Mask [Internet]. Vol. 12, Emerging Infectious Diseases. 2006. p. 1033-4. Available from: http://dx.doi.org/10.3201/eid1206.051468

45. Long Y, Hu T, Liu L, Chen R, Guo Q, Yang L, et al. Effectiveness of N95 respirators versus surgical masks against influenza: A systematic review and meta-analysis [Internet]. Vol. 13, Journal of Evidence-Based Medicine. 2020. p. 93-101. Available from: http://dx.doi.org/10.1111/jebm.12381

46. MacIntyre CR, Seale H, Dung TC, Hien NT, Nga PT, Chughtai AA, et al. A cluster randomised trial of cloth masks compared with medical masks in healthcare workers [Internet]. Vol. 5, BMJ Open. 2015. p. e006577-e006577. Available from: http:// dx.doi.org/10.1136/bmjopen-2014-006577

47. Leung NHL, Chu DKW, Shiu EYC, Chan K-H, McDevitt JJ, Hau BJP, et al. Author Correction: Respiratory virus shedding 
in exhaled breath and efficacy of face masks [Internet]. Nature Medicine. 2020. Available from: http://dx.doi.org/10.1038/ s41591-020-0946-9

48. Davies A, Thompson K-A, Giri K, Kafatos G, Walker J, Bennett A. Testing the Efficacy of Homemade Masks: Would They Protect in an Influenza Pandemic? [Internet]. Vol. 7, Disaster Medicine and Public Health Preparedness. 2013. p. 413-8. Available from: http://dx.doi.org/10.1017/dmp.2013.43

49. Zhou W, Tao L, Geng M, Lyu H. Trend Prediction and Intervention of the COVID-19 Pandemic: A Modelling Study [Internet]. SSRN Electronic Journal. Available from: http://dx.doi. org/10.2139/ssrn.3576823

50. Takahashi H, Kasuga R, Miya S, Miyamura N, Kuda T, Kimura B. Efficacy of Propidium Monoazide on Quantitative Real-Time PCR-Based Enumeration of Staphylococcus aureus Live Cells Treated with Various Sanitizers [Internet]. Vol. 81, Journal of Food Protection. 2018. p. 1815-20. Available from: http:// dx.doi.org/10.4315/0362-028x.jfp-18-059

51. Vermeil T, Peters A, Kilpatrick C, Pires D, Allegranzi B, Pittet D. Hand hygiene in hospitals: anatomy of a revolution [Internet]. Vol. 101, Journal of Hospital Infection. 2019. p. 383-92. Available from: http://dx.doi.org/10.1016/j.jhin.2018.09.003

52. Greenaway RE, Ormandy K, Fellows C, Hollowood T. Impact of hand sanitizer format (gel/foam/liquid) and dose amount on its sensory properties and acceptability for improving hand hygiene compliance. J Hosp Infect. 2018 Oct;100(2):195-201.

53. Stebbins S, Cummings DAT, Stark JH, Vukotich C, Mitruka K, Thompson W, et al. Reduction in the Incidence of Influenza A But Not Influenza B Associated With Use of Hand Sanitizer and Cough Hygiene in Schools [Internet]. Vol. 30, The Pediatric Infectious Disease Journal. 2011. p. 921-6. Available from: http:// dx.doi.org/10.1097/inf.0b013e3182218656

54. Larson EL, Ferng Y-H, McLoughlin JW, Wang S, Morse SS. Effect of Intensive Education on Knowledge, Attitudes, and Practices Regarding Upper Respiratory Infections Among Urban Latinos [Internet]. Vol. 58, Nursing Research. 2009. p. 150-7. Available from: http://dx.doi.org/10.1097/nnr.0b013e3181a30951

55. Thu LTA, Le Thi Arm T, Dibley MJ, Van Nho V, Archibald L, Jarvis WR, et al. Reduction in Surgical Site Infections in Neurosurgical Patients Associated With a Bedside Hand Hygiene Program in Vietnam [Internet]. Vol. 28, Infection Control \& Hospital Epidemiology. 2007. p. 583-8. Available from: http://dx.doi. org/10.1086/516661

56. Knighton SC, McDowell C, Rai H, Higgins P, Burant C, Donskey CJ. Feasibility: An important but neglected issue in patient hand hygiene. Am J Infect Control. 2017 Jun 1;45(6):626-9.

57. Kirk J, Kendall A, Marx JF, Pincock T, Young E, Hughes JM, et al. Point of care hand hygiene-where's the rub? A survey of US and Canadian health care workers' knowledge, attitudes, and practices [Internet]. Vol. 44, American Journal of Infection Control. 2016. p. 1095-101. Available from: http://dx.doi. org/10.1016/j.ajic.2016.03.005

58. Wilder-Smith A, Freedman DO. Isolation, quarantine, social distancing and community containment: pivotal role for old-style public health measures in the novel coronavirus (2019-nCoV) outbreak [Internet]. Vol. 27, Journal of Travel Medicine. 2020. Available from: http://dx.doi.org/10.1093/jtm/taaa020

59. Harsha L, Brundha MP. Prevalence of dental developmental anomalies among men and women and its psychological effect in a given population. J Pharm Sci [Internet]. 2017; Available from: http://search.proquest.com/openview/1f488cc6e377096f4 4a87e 509aceab79/1?pq-origsite $=$ gscholar $\& \mathrm{cbl}=54977$
60. Lander AD. Releasing the lockdown in the UK Covid-19 epidemic: a stochastic model [Internet]. Available from: http:// dx.doi.org/10.1101/2020.04.28.20083329

61. Rachlin H. Lucy's Bones, Sacred Stones, \& Einstein's Brain: The Remarkable Stories Behind the Great Objects and Artifacts of History, From Antiquity to the Modern Era. Garrett County Press; 2013. 309 p.

62. Times TNY, The New York Times. New York Times New York City Poll, April 2004 [Internet]. ICPSR Data Holdings. 2004. Available from: http://dx.doi.org/10.3886/icpsr04094

63. Troko J, Myles P, Gibson J, Hashim A, Enstone J, Kingdon S, et al. Is public transport a risk factor for acute respiratory infection? [Internet]. Vol. 11, BMC Infectious Diseases. 2011. Available from: http://dx.doi.org/10.1186/1471-2334-11-16

64. Ettema D, Gärling T, Olsson LE, Friman M. Out-of-home activities, daily travel, and subjective well-being [Internet]. Vol. 44, Transportation Research Part A: Policy and Practice. 2010. p. 723-32. Available from: http://dx.doi.org/10.1016/j. tra.2010.07.005

65. Panik RT, Morris EA, Voulgaris CT. Does walking and bicycling more mean exercising less? Evidence from the U.S. and the Netherlands [Internet]. Vol. 15, Journal of Transport \& Health. 2019. p. 100590. Available from: http://dx.doi.org/10.1016/j. jth.2019.100590

66. Lewnard JA, Lo NC. Scientific and ethical basis for socialdistancing interventions against COVID-19 [Internet]. Vol. 20, The Lancet Infectious Diseases. 2020. p. 631-3. Available from: http://dx.doi.org/10.1016/s1473-3099(20)30190-0

67. Xu Z. Can common coronavirus compete with novel coronavirus? [Internet]. Available from: http://dx.doi.org/10.31219/osf. io/drtgp

68. Kucharski AJ, Althaus CL. The role of superspreading in Middle East respiratory syndrome coronavirus (MERS-CoV) transmission. Euro Surveill. 2015 Jun 25;20(25):14-8.

69. Kumar MDA, Brundha MP. Awareness about nocturia-A questionnaire survey. Research Journal of Pharmacy and Technology. 2016;9(10):1707-9.

70. Al-Tawfiq JA, Auwaerter PG. Healthcare-associated infections: the hallmark of Middle East respiratory syndrome coronavirus with review of the literature [Internet]. Vol. 101, Journal of Hospital Infection. 2019. p. 20-9. Available from: http://dx.doi. org/10.1016/j.jhin.2018.05.021

71. Li Q, Guan X, Wu P, Wang X, Zhou L, Tong Y, et al. Early Transmission Dynamics in Wuhan, China, of Novel Coronavirus-Infected Pneumonia [Internet]. Vol. 382, New England Journal of Medicine. 2020. p. 1199-207. Available from: http:// dx.doi.org/10.1056/nejmoa2001316

72. Prashaanthi N, Brundha MP. A Comparative Study between Popplet Notes and Conventional Notes for Learning Pathology [Internet]. Vol. 11, Research Journal of Pharmacy and Technology. 2018. p. 175. Available from: http://dx.doi.org/10.5958/0974360x.2018.00032.x

73. Ahmed AE. Estimating survival rates in MERS-CoV patients 14 and 45 days after experiencing symptoms and determining the differences in survival rates by demographic data, disease characteristics and regions: a worldwide study [Internet]. Vol. 146, Epidemiology and Infection. 2018. p. 489-95. Available from: http://dx.doi.org/10.1017/s095026881700293x

74. Brundha MP, Pathmashri VP, Sundari S. Quantitative Changes of Red Blood cells in Cancer Patients under Palliative Radiotherapy-A Retrospective Study [Internet]. Vol. 12, Research 
Journal of Pharmacy and Technology. 2019. p. 687. Available from: http://dx.doi.org/10.5958/0974-360x.2019.00122.7

75. Patil SS, Mali SS, Patil RR, Kore PS. Zika Virus: Infection, Virus, Development and Process of Vaccines [Internet]. Vol. 11, Research Journal of Pharmacy and Technology. 2018. p. 5159. Available from: http://dx.doi.org/10.5958/0974360x.2018.00942.3
76. Geise JP. Public and Private in Social Life. Edited by S. I. Benn and G. F. Gaus. (New York: St. Martin's Press, 1983. Pp. vii 412. \$35.00.) [Internet]. Vol. 78, American Political Science Review. 1984. p. 1181-1181. Available from: http://dx.doi. org/10.2307/1955920

77. Bank W, World Bank. Europe and Central Asia Economic Update, Spring 2020: Fighting COVID-19 [Internet]. 2020. Available from: http://dx.doi.org/10.1596/978-1-4648-1564-5. 